\title{
Bł. Edmund Bojanowski, założyciel Zgromadzenia Sióstr Służebniczek - nowe zgromadzenie zakonne w trudnym okresie kasat w zaborze pruskim
}

\section{Wstęp}

$\bigvee_{\text {trudnym okresie kasat domów zakonnych w zaborze pruskim, dokładnie }}$ V na obszarze Wielkopolski, powstało Zgromadzenie Sióstr Służebniczek. Było to możliwe, z jednej strony dzięki determinacji jego założyciela Edmunda Bojanowskiego, z drugiej natomiast dzięki charakterowi posługi, której podjęła się ta nowa wspólnota. W niniejszym artykule przyjrzymy się w syntetycznym ujęciu genezie powstania oraz początkom wspólnoty sióstr służebniczek, dokładnie w okresie do 1871 roku, czyli do śmierci E. Bojanowskiego. Podjęty temat przedstawimy głównie z perspektywy relacji nowego dzieła, zarówno do władz kościelnych, jak i świeckich. Wydaje się, że na przykładzie historii Zgromadzenia Sióstr Służebniczek można ukazać, z jednej strony specyfikę nowych form życia konsekrowanego, które spotykamy w całym Kościele w XIX wieku (w tym również na obszarze Polski podzielonej między trzech zaborców), $z$ drugiej natomiast także na wyjątkowo trudny i skomplikowany charakter okresu zaborów, w którym przyszło powstawać oraz funkcjonować tym nowym wspólnotom zakonnym.

\footnotetext{
* Dк. Waldemar Rozynkowski; diakon stały diecezji toruńskiej, prof. zw. dr hab., historyk, specjalizacja naukowa: historia kościoła, pracownik Instytutu Historii i Archiwistyki Uniwersytetu Mikołaja Kopernika w Toruniu. E-mail:wr@umk.pl.
} 


\section{Założyciel}

Założycielem zgromadzenia był Edmund Bojanowski, przybliżmy więc jego postać. Urodził się 14 XI 1814 roku w miejscowości Grabonóg koło Gostynia ${ }^{1}$. Pochodził ze średnio zamożnej rodziny ziemiańskiej, studiował we Wrocławiu i Berlinie, studiów jednak nie ukończył ze względu na zły stan zdrowia. Po powrocie do Grabonoga w 1839 roku zajął się pracą społeczną, głównie pośród mieszkańców wsi. Bardzo szybko włączył się w prace Kasyna Gostyńskiego, znanej w Wielkopolsce organizacji, która prowadziła szeroką działalność kulturalną, oświatową oraz społeczną. Początkowo związał się przede wszystkim $\mathrm{z}$ wydziałem literackim tej organizacji. Edmund Bojanowski wniósł do niej inicjatywę zbierania, utrwalania i zachowania folkloru oraz organizowania wiejskich czytelni przy szkołach. Współpracował z pismem „Przyjaciel Ludu” oraz był współredaktorem rocznika „Pokłosie” i czasopisma „Rok Wiejski”. W 1857 roku, w uznaniu zasług na polu literackim, Poznańskie Towarzystwo Przyjaciół Nauk wybrało go na swojego członka.

Nowe pole działalności Bojanowskiego związane było z doświadczeniem epidemii cholery, która dotknęła w 1848 roku Wielkopolskę. Jej następstwem była, między innymi, wielka liczba sierot, które wymagały opieki. Dzięki pomocy okolicznych ziemian w 1849 roku sprowadził on do Gostynia, do pomieszczeń po Kasynie, Zgromadzenie Sióstr Miłosierdzia św. Wincentego à Paulo (siostry szarytki), które zajęły się opieką i pielęgnacją sierot oraz chorych dzieci.

W 1868 roku E. Bojanowski musiał opuścić rodzinny Grabonóg i zamieszkał u przyjaciela ks. Jana Koźmiana w Poznaniu. 30 III 1869 roku, czyli w wieku pięćdziesięciu pięciu lat, wstąpił do Arcybiskupiego Seminarium Duchownego w Gnieźnie, nie przebywał w nim jednak długo. Ze względu na pogarszający się stan zdrowia 2 V 1870 roku musiał opuścić seminarium. Zmarł 7 VIII 1871 roku w Górce Duchownej koło Leszna. Został beatyfikowany 13 VI 1999 roku w Warszawie przez papieża Jana Pawła II.

${ }^{1}$ Postaci E. Bojanowskiego oraz jego dziełom poświęcono wiele prac, zob. np.: W. Muchowicz, Żywot Edmunda Bojanowskiego Założyciela Ochronek na ziemiach Polskich i Zgromadzenia S.S. Służebniczek B.R.D.N.P., Rzeszów 1933; A. Szelęgiewicz, Edmund Bojanowski i jego dzieło, Poznań 1966; M. Kornacka, Edmund Bojanowski 1814-1871, „Nasza Przeszłość” 1967, t. 26, s. 5-145; S. Chociej, Twórczość literacka i działalność wydawnicza Edmunda Bojanowskiego, „Nasza Przeszłość” 1967, t. 26, s. 147-218; J. Rehmus, Edmund Bojanowski, w: Hagiografia polska, t. 1, red. R. Gustaw, Poznań 1971, s. 159-176; B. Biel, Edmund Bojanowski 1814-1871, w: Chrześcijanie, t. 1, red. B. Bejze, Warszawa 1974, s. 87-106; M. Kornacka, Bojanowski Edmund, w: Encyklopedia Katolicka, t. 2, Lublin 1985, kol. 738-739; J. Misiurek, Historia i teologia polskiej duchowości katolickiej, t. 2, (w. XVIII-XIX), Lublin 1998, s. 218-223; A. Pękala, Od pracy organicznej do świętości, w: Błogosławiony Edmund Bojanowski serdecznie dobry człowiek, red. S. Wilk, Lublin 2000, s. 21-48. 


\section{Początki zgromadzenia}

Największym dziełem E. Bojanowskiego było założenie żeńskiego zgromadzenia zakonnego. Jego geneza sięga połowy XIX wieku, kiedy to Edmund zaczął organizować ochronki wiejskie, które miały pomagać w wychowaniu dzieci, których rodzice zajęci byli przede wszystkim pracą, a także dla dzieci, które nie miały opieki w domach rodzinnych lub były sierotami. Inspiracje do tego dzieła znalazł E. Bojanowski w spotkaniach z Augustem Cieszkowskim, a szczególnie w jego dziele O ochronach wiejskich ${ }^{2}$. Dodajmy, że A. Cieszkowski przedstawił swoją wizję otoczenia opieką wiejskich dzieci na posiedzeniu wydziału literackiego Kasyna Gostyńskiego, które miało miejsce w maju 1842 roku $^{3}$. E. Bojanowski zapalił się do dzieła ochronek i to właśnie przede wszystkim on zaczął wprowadzać w czyn w środowisku wiejskim myśl, która krążyła w wielu umysłach.

Oczywistym stało się to, że do pracy w tych miejscach potrzeba było osób, a z biegiem czasu odniesienia do instytucji, która nadałaby dziełu stabilny charakter. Początkowo E. Bojanowski wsparcia szukał u sióstr szarytek, które sprowadził do Gostynia. Zauważmy, że nie było łatwo znaleźć pośród ówczesnych wspólnot kościelnych, takiej, która mogłaby pomóc zrealizować myśl oraz podtrzymać wykluwające się powoli dzieło. W życiu zakonnym ogromne spustoszenie poczynił przecież zaborca. W 1815 roku w granicach Księstwa Poznańskiego znajdowało się 47 klasztorów męskich z 464 zakonnikami oraz 10 żeńskich ze 119 zakonnicami ${ }^{4}$. W 1848 roku w granicach archidiecezji gnieźnieńskiej i archidiecezji poznańskiej był tylko jeden dom zakonny żeński. Chodzi tu dokładnie o dom sióstr miłosierdzia św. Wincentego à Paulo w Poznaniu.

Brak zakonów, a szczególnie sióstr był widoczny między innymi na polu pracy wychowawczej i charytatywnej prowadzonej od pokoleń przez Kościół. W XIX wieku zmieniły się oczywiście realia i warunki zewnętrzne, a w samym Kościele pojawiły się nowe dzieła, myślimy tu o czynnych zgromadzeniach zakonnych. Proces zmian w wielu miejscach odbywał się stopniowo, ewolucyjnie. Na obszarze Wielkopolski, w granicach zaboru pruskiego, było oczywiście inaczej, bardziej drastycznie. Czyniono jednak i tu starania o pozyskanie czynnych zgromadzeń zakonnych i przyniosły one pewne rezultaty, np. do Poznania w 1857 roku sprowadzono Urszulanki Unii Rzymskiej oraz siostry ze Zgromadzenia Najświętszego Serca Jezusa (Sacré-Coeur)5.

2 A. Cieszkowski, O ochronach wiejskich, Poznań 1842; M. Opiela, Integralna pedagogika przedszkolna w systemie wychowania Edmunda Bojanowskiego. Kontynuacja i zmiana, Lublin 2013, s. 27.

${ }^{3}$ M. Kornacka, Edmund Bojanowski..., s. 46-47.

${ }^{4}$ P.P. Gach, Kasaty zakonów na ziemiach dawnej Rzeczypospolitej i Śląska 1773-1914, Lublin 1984, s. 126.

5 Tamże, s. 227. 
Jak już wspomniano w 1849 roku z inicjatywy E. Bojanowskiego powołano do istnienia nowy dom sióstr miłosierdzia poza Poznaniem, mianowicie w Gostyniu. Dom ten połączony był ze szpitalem oraz sierocińcem ${ }^{6}$. Pojawienie się tej fundacji sióstr miłosierdzia w Gostyniu oznaczało, że Bojanowski miał swój udział także w rozwoju tegoż zgromadzenia w trudnym czasie pokasatowym w zaborze pruskim. Dodajmy jednocześnie, że siostry miłosierdzia oraz założone rok później siostry służebniczki były wspólnotami, które w Wielkopolsce od połowy XIX wieku rozwijały się najdynamiczniej spośród wszystkich innych zgromadzeń zakonnych ${ }^{7}$.

Przejdźmy bezpośrednio do interesującej nas wspólnoty sióstr służebniczek. Za początek dzieła nowego zgromadzenia uważa się powszechnie w historiografii 3 V 1850 roku, kiedy to w miejscowości Podrzecze, niedaleko Gostynia, E. Bojanowski otworzył ochronkę. Do jej prowadzenia zebrała się grupa dziewcząt, które chciały poświęcić się pracy jako opiekunki. Dodajmy, że prawdopodobnie nikt nie przypuszczał, że w przyszłości na bazie tego dzieła powstanie nowe zgromadzenie zakonne. Wydaje się, że i sam E. Bojanowski zamierzał pierwotnie powołać do istnienia prawdopodobnie tylko bractwo ochroniarek. Życie codzienne funkcjonującego dzieła przynosiło jednak jego założycielowi nowe światło. Stało się oczywistym, że misja ochronek wymagała trwałej wspólnoty. I tak dochodzimy do formowania się nowego zgromadzenia zakonnego. Jednoznacznie dzieło zgromadzenia zaczął realizować E. Bojanowski od 1855 roku. Jak widać, trzeba było doświadczeń pięciu lat, aby wyraźnie skierować podjętą działalność na te właśnie tory. W liście do abpa Leona Przyłuskiego z 8 XII 1855 roku E. Bojanowski napisze tak: „Rozwijająca się myśl cała musiała przyjąć kształty wyraźne, a że w takim razie najpewniejsza jest droga tradycji kościelnej, starałem się nadać jej podobny charakter"8. Możemy przypuszczać, że E. Bojanowski, odwołując się do tradycji, myślał o bogatym doświadczeniu życia konsekrowanego w Kościele.

Już 24 II 1855 roku E. Bojanowski wysłał do Rzymu do zmartwychwstańców: ks. Hieronima Kajsiewicza oraz ks. Piotra Semenenki list, w którym naszkicował ramy organizacyjne życia - pierwszą regułę - wspólnoty Służebnic Najświętszej Panny. Odpowiedź otrzymał w liście z 26 V 1855 roku, do którego dołączono zredagowaną przez zakonników Regułę Służebniczek Bogarodzicy ${ }^{9}$.

W maju 1855 roku została otwarta ochronka w miejscowości Turwia, w majątku generała Dezyderego Chłapowskiego. Była to trzecia z kolei ochronka.

${ }^{6}$ Zob. Z. Zieliński, Kościót katolicki w Wielkim Księstwie Poznańskim w latach 1848-1865, Lublin 1973, s. 226, 228.

7 Tamże, s. 229.

${ }^{8}$ Korespondencja Edmunda Bojanowskiego z lat 1829-1871, t. 1, Listy Edmunda Bojanowskiego z lat 1836-1871, wyd. L. Smołka, Wrocław 2001, s. 169 (dalej: Listy).

${ }_{9}$ M. Kornacka, Edmund Bojanowski..., s. 55-58. 
W jej kontekście ważnym podkreślenia jest to, że prawdopodobnie po raz pierwszy w odniesieniu do ochroniarek użyto określenia siostry. W świetle zapisów w Dzienniku E. Bojanowski zaznaczył, że tak nazywał je sam generał oraz „wszyscy ludzie”, czyli zapewne ci, którzy mieli styczność z dziewczętami prowadzącymi dzieło ochronki ${ }^{10}$.

Nie znamy pierwszych ochroniarek. Trzeba również zauważyć, że ich początkowe zobowiązania nie posiadały charakteru ślubów zakonnych. Poza dobrym stanem zdrowia, kandydatki na ochroniarki musiały spełniać trzy podstawowe warunki: młody wiek (później określono go między 14 a 30 rokiem życia), życie w stanie wolnym oraz wiejskie pochodzenie ${ }^{11}$. Ten ostatni warunek odsłania specyfikę omawianego dzieła. Podstawę utrzymania ochronek stanowiła bowiem praca opiekunek, i to nie codziennie pośród dzieci. Pierwsze ochroniarki miały zapewnić sobie oraz prowadzonemu dziełu utrzymanie poprzez pracę fizyczną. Każda z nich zajmowała się dziećmi co trzeci dzień, dwa dni zaś pracowała na swoje utrzymanie, głównie poprzez prace w polu i ogrodzie.

$\mathrm{Z}$ biegiem czasu, organizacja ochronek oraz funkcjonujących przy nich wspólnot zmieniała się i zaczęła coraz bardziej przypominać dzieło zakonne. W ciekawych słowach scharakteryzował E. Bojanowski swoje dzieło ks. abp Leonowi Przyłuskiemu w liście z 13 VI 1858 roku (czyli po ośmiu latach jego funkcjonowania), porównując je ze znaną działalnością sióstr miłosierdzia. Oddajmy głos założycielowi:

„[...] urządzenie zakładu Sióstr Miłosierdzia nie odpowiada drobnej skali i zwykłemu trybowi wieśniaczego życia, z którego pochodzą i do którego się kształcić mają wiejskie kandydatki ochronkowe. Same porządki i przyrządy gospodarstwa domowego, sam obrót zatrudnień, właściwe zakładowi większych rozmiarów, nie przypadają do ograniczonych środków wiejskiego zarządu domowego. Przyzwyczajenie się do przestronnych sal, wygodnych zachowań i.t.p. mogłoby się było stać łatwo powodem nieukontentowania się potem ciasną izdebką wiejską. Również i co do jadła u Sióstr Miłosierdzia przez konieczny wzgląd na sieroty w stanie największego zanędznienia przybywające do zakładu, dawane bywa mięso kilka razy na tydzień, gdy tymczasem kandydatki ochronkowe przyzwyczaiwszy się do tego, potem na wsi zaledwo kilka razy do roku mogłyby mieć mięso na stole.

$\mathrm{Z}$ tych i tym podobnych powodów powziąłem przeświadczenie, że zakład ochronkowy Służebniczek Boga-Rodzicy, jako wyłącznie dla wiosek przeznaczony, różni się tak stanowczo od instytucji na wyższą stopę miejską urządzonych, a w tem samem i od instytucji Sióstr Miłosierdzia, iż powinien koniecznie

${ }^{10}$ E. Bojanowski, Dziennik, objaśnił, skomentował i wstępem poprzedził L. Smołka, t. 1, Wrocław 2009, s. 679 (3 VII 1855), (dalej: Dziennik).

11 M. Fąka, Ziarno wrzucone w ziemię. Edmund Bojanowski (1814-1871). Założyciel Zgromadzenia Sióstr Służebniczek N.M.P. Niepokalanie Poczętej, Wrocław 1988, s. 44-45. 
rozwijać się osobno i samorodnie, wedle właściwych swemu przeznaczeniu warunków"12.

Jak skromne były początki nowego dzieła, w pierwszych latach jego funkcjonowania, czytamy w liście E. Bojanowskiego do Zygmunta Szułdrzyńskiego z 20 VII 1861 roku. Założyciel ochronek w następujących słowach opisał oczekiwania co do miejsca:

„Co do urządzenia domku nadmieniam tu tylko tymczasem, że jest potrzebna osobna sionka, za nią izba, stosownie do ilości dzieci, obszerna i druga izdebka sypialna ogrzewana dla trzech służebniczek, ponieważ zawsze trzy do jednej ochronki się przeznacza.

Dalej co do sprzętów, warunków utrzymania itd., jakkolwiek są bardzo skromne i nieliczne pomijam

1) drzwi klauzurowe od wejścia zamykane na zamek, w nich okienko ze zasuwką, a przy drzwiach dzwonek,

2) izba stosownie do ilości dzieci obszerna,

3) izdebka ogrzewana także, jako sypialnia dla trzech służebniczek, ponieważ zawsze trzy do każdej ochronki się przeznacza, a nigdy mniej,

4) piecyk do pieczenia chleba, sklepik,

5) chlewik przy domku,

6) mały ogródek lub miejsce, ile możności, ocienione, ogrodzone dla dzieci.

Co do kosztów urządzenia, sprzętów i warunków utrzymania, te są bardzo skromne - mniej więcej takie, jak potrzebuje każda wiejska rodzina"13.

\section{Droga w Kościele}

Wydaje się, że największym wyzwaniem dla powstającego dzieła zakonnego była przede wszystkim akceptacja ze strony władz kościelnych. Chodzi tu przede wszystkim o akceptację ze strony arcybiskupa metropolii poznańsko-gnieźnieńskiej, to on przecież odegrał w pierwszym okresie powstającego zgromadzenia kluczową rolę. Wiemy, że do dzieła nie był entuzjastycznie nastawiony ks. abp Leon Przyłuski, który urząd swój sprawował w latach 1845-1865. Dodajmy, że był to bardzo trudny okres dla życia zakonnego na obszarze archidiecezji, gdyż było ono obecne w jej granicach w szczątkowej formie. Przychylniejsze nastawianie do powstającego dzieła miał abp Mieczysław Halka Ledóchowski, który swoją posługę piastował w latach 1866-1886.

Kluczową rolę w historii dzieła, nie zawsze jednak pozytywną, odegrali także konkretni księża proboszczowie oraz administratorzy parafii. To przecież oni na

\footnotetext{
12 Listy, t. 1, s. 199.

13 Tamże, s. 263-264.
} 
poziomie prowincji, często niewielkich parafii, mieli do czynienia z powstającym dziełem i oni byli jego pierwszymi recenzentami. Pośród nich zaczęła budzić coraz większe zainteresowanie instytucja ochronek oraz powstające zgromadzenie. Nie można również zapomnieć o księżach filipinach ze Świętej Góry koło Gostynia, którzy zarówno w życiu E. Bojanowskiego, jak w początkach dzieła wiejskich ochronek odegrali ogromną rolę.

Jak już wspomniano, trudno do końca rozstrzygnąć, czy w zamyśle inicjatora, powstająca przy ochronkach wspólnota od początku miała zmierzać w kierunku powstania zgromadzenia zakonnego. Widać jednak wyraźnie, że po pewnym czasie ewaluowało ono właśnie w tę stronę. Kiedy E. Bojanowski coraz bardziej definiował życie ochroniarek, odwoływał się w znacznej mierze do sprawdzonych praktyk zakonnych opartych na: modlitwie, życiu sakramentalnym, życiu wspólnotowym itd.

Początkowo dzieło rozwijało się dyskretnie i powoli. Przez pierwsze cztery lata funkcjonowała tylko jedna ochronka w Podrzeczu. Największym wyzwaniem w dziele E. Bojanowskiego stawała się obecność ochroniarek. Życie pokazało, że trzeba będzie podejmować nowe decyzje, co do ich statusu w Kościele. W lipcu 1854 roku ochroniarki podrzeckie przeżyły rekolekcje. Na ich zakończenie włożyły jednakowe błękitne suknie oraz białe sztywne chustki ${ }^{14}$. Nie była to znacząca oryginalność w środowisku wiejskim, jednak dla powstającej wspólnoty zakonnej był to moment niezwykle ważny.

Bardzo szybko okazało się, że potrzebny był również okres formacji wstępnej dla ochroniarek - w odniesieniu do zakonów myślimy tu o postulacie czy o nowicjacie. E. Bojanowski używał początkowo wobec tej rzeczywistości określenia seminarium. W Dzienniku pod datą 24 II 1855 roku czytamy, że „wydział seminaryjny dla ochotniczek wiejskich” zamierzał uczynić w domu sióstr miłosierdzia w Gostyniu ${ }^{15}$. Wedle wstępnych planów opłata roczna, na rzecz sióstr miłosierdzia, za jedną przyszłą ochroniarkę miała wynosić 30 talarów. Przełożoną kandydatek miała być siostra służebniczka. Po uzyskaniu zgody sióstr miłosierdzia liczbę kandydatek - ochroniarek - ustalono na $12^{16}$. Zadbanie już w tym czasie, tj. w 1855 roku, o okres przygotowawczy dla dziewcząt do pracy w ochronkach i to na dodatek w zgromadzeniu zakonnym wskazuje na to, że już na tym etapie E. Bojanowski kierował tworzone dzieło na tory zakonne.

Bliskie związki pierwszych służebniczek z siostrami szarytkami sprawiły, że pojawiły się nawet głosy, aby powstające dzieło powiązać z tym właśnie zgromadzeniem. Przyjaciel Bojanowskiego ks. Antoni Brzeziński pisał do niego w liście z 4 IV 1855 roku: „Uważam za rzecz konieczną, aby nowy ten związek kościelny

\footnotetext{
14 M. Fąka, Ziarno..., s. 50.

15 Dziennik, t. 1, s. 583 (24 II 1855 rok).

16 Tamże, s. 732 (2 X 1855 rok).
} 
uważany był za gałąź Zgromadzenia Córek Miłos[ierdzia] Św. Wincentego, bo pewniejsza jego będzie przyszłość i w samym założeniu swym więcej by miał mocy"17. Wiemy, że E. Bojanowski nie poszedł jednak za radą przyjaciela.

Po pewnym czasie okazało się jednak, że obecność przyszłych ochroniarek u sióstr miłosierdzia w gostyńskim domu stawała się problematyczna. Trudno było bowiem funkcjonować pod jednym dachem dwóm wspólnotom, z których jedna dopiero definiowała swoje zręby. Sytuacja wymusiła założenie odrębnego domu formacyjnego. Stało się to w 1856 roku. E. Bojanowski wydzierżawił dom parafialny w Jaszkowie koło Śremu. Uroczyste otwarcie nowicjatu miało miejsce 26 sierpnia tegoż roku. Dodajmy, że według planów i wstępnych ustaleń dom ten miał pozostać pod duchową opieką jezuitów ze Śremu ${ }^{18}$. Z inicjatywy zakonników pojawił się nawet pomysł, aby nowicjat służebniczek otworzyć niedaleko klasztoru w Śremie ${ }^{19}$. Odnotujmy, że w tym czasie jezuici sami definiowali na nowo swoją obecność w Wielkopolsce (po kasacie). W Śremie, a dokładnie w klasztorze po klaryskach, pojawili się w 1854 roku, niestety zostali z niego usunięci w 1872 roku $^{20}$.

Kiedy dzieło ochronek zaczęło wyraźnie wchodzić na tory zgromadzenia zakonnego, pojawiła się kwestia formalnej obecności w nim jego założyciela Edmunda Bojanowskiego. W projekcie reguły zaznaczono, że służebniczki miały być posłuszne przełożonemu generalnemu oraz przełożonej generalnej, którzy mogli pochodzić zarówno ze stanu duchownego, jak i świeckiego. To ostatnie stwierdzenie wskazuje wyraźnie, że próbowano znaleźć formułę obecności w zgromadzeniu dla jego założyciela ${ }^{21}$.

Widać, że po pewnym czasie funkcjonowania już konkretnej wspólnoty ochroniarek obecność w niej E. Bojanowskiego stała się, przynajmniej dla niektórych, problematyczna. O dziwo jednymi z pierwszych, którzy zaczęli podawać w wątpliwość wymiar jego obecności w tworzącym się dziele zgromadzenia, byli księża. Ilustracją przywołanej tu rzeczywistości niech będą słowa ks. Marcina Hübnera, filipina ze Świętej Góry koło Gostynia, który przez lata był spowiednikiem służebniczek i najbliższym współpracownikiem E. Bojanowskiego. Miał on odebrać pierwsze śluby, o charakterze prywatnym, od ochroniarek. Jednak w liście do E. Bojanowskiego z 24 III 1855 roku napisał bardzo mocne słowa: „Co do mnie, uważam za rzecz nieprzyzwoitą, a nawet niebezpieczną, aby dziewice świeckiej osobie, a do tego mężczyźnie posłuszeństwo ślubować miały, a świecka osoba nie powinna się mieszać do interesów sumienia osób zakonnych"22.

17 Listy, t. 2, s. 123.

18 Dziennik, t. 2, s. 102-105 (26 VIII 1856 rok); A. Szelęgiewicz, Edmund Bojanowski..., s. 56 i nn.; M. Kornacka, Edmund Bojanowski..., s. 78-79.

19 A. Szelęgiewicz, Edmund Bojanowski..., s. 55.

${ }^{20}$ Encyklopedia wiedzy o jezuitach, oprac. L. Grzebień, Kraków 1996, s. 677.

${ }^{21}$ M. Fąka, Ziarno..., s. 51.

22 Listy, t. 2, s. 121; M. Fąka, Ziarno..., s. 52. 
W Dzienniku E. Bojanowskiego możemy wyczytać, że niektórzy, w tym i duchowni, uprzedzali kandydatki chcące dołączyć do wspólnoty ochroniarek, wskazując, że przestanie ona istnieć wraz ze śmiercią jej inicjatora. Czasami nawet duchowni wprost zakazywali dziewczętom wstępowania do służebniczek. Odwołajmy się do zapisów samego E. Bojanowskiego, które spotykamy w Dzienniku:

- „Przyszły do mnie kandydatki pruskie od sióstr, zniechęcone i zatrwożone nagadanemi im obawami, że skoro bym ja umarł, Ochronki się rozbiją, a gdyby dłuższy czas zostały w tej służbie, to odarte, bez niczego wrócą na starość do swoich itd. Skąd te wpływy odstręczające pochodzą, wybadać nie mogłem" [2 I 1856 rok $]^{23}$.

- „Zastałem w gościnnym pokoju ks. Preibisza i cztery kandydatki ochronkowe [...] Niespodzianie wszystkie oświadczają mi, że nie chcą być w służbie ochronkowej i że chcą wrócić do domu. Ks. P[reibisz] stawa w ich imieniu, obwinia mnie, a szczególniej o. B[aczyńskiego] o niesumienne, kłamliwe oszukanie tych dziewczyn, że myślały pójść do zakonu, a znalazły służbę ochroniarek, która jest tyle co nic itp. itp." [18 II 1956 rok] ${ }^{24}$.

- „Mówiła mi także [Jagusia] o Apolonii, która służy u Przewoźnej, że pomimo jej najgorliwszej chęci wstąpienia do Służebniczek, spowiednik zabrania jej tego, a doradza iść w służbę do brata swego" [9 X 1856 rok ${ }^{25}$.

Najtrudniejsze lata doświadczeń dla dzieła oraz jego twórcy obejmowały lata 1855-1858 ${ }^{26}$. Wspólnota służebniczek rozwijała się jednak dalej. E. Bojanowski podejmował kolejne decyzje, które prowadziły ochroniarki w kierunku nowego zgromadzenia zakonnego.

Symbolicznym wydarzeniem w historii wspólnoty było udzielenie 11 IV 1859 roku przez papieża Piusa IX błogosławieństwa dla sióstr służebniczek oraz samego E. Bojanowskiego ${ }^{27}$. Z prawnego punktu widzenia niezwykle istotny był dokument, który wystawił arcybiskup Mieczysław Halka Ledóchowski. Dnia 27 XII 1866 roku wydał on dekret pochwalny dla Zgromadzenia Służebniczek Boga Rodzicy Dziewicy Niepokalanie Poczętej oraz zatwierdził jego regułę, którą E. Bojanowski w roku następnym wydał drukiem w Poznaniu ${ }^{28}$.

23 Dziennik, t. 2, s. 6.

24 Dziennik, t. 2, s. 27.

${ }_{25}$ Dziennik, t. 2, s. 126.

26 A. Szelęgiewicz, Edmund Bojanowski..., s. 49.

27 Dziennik, t. 2, s. 591 (23 V 1859 rok).

28 Reguła Zgromadzenia Służebniczek Boga Rodzicy Dziewicy Niepokalanie Poczętej, wydana drukiem nakładem Bojanowskiego, Poznań 1967. 


\section{Stosunek władzy świeckiej}

W pismach E. Bojanowskiego spotykamy bardzo mało informacji o stosunku władzy świeckiej w Wielkopolsce do powstającego dzieła. W świetle zachowanego dziennika, listów E. Bojanowskiego oraz przychodzącej do niego korespondencji nie dostrzegamy jakiegoś konfliktu czy trudności ze strony władz. Bezpośrednie represje wobec powstającego zgromadzenia w Wielkopolsce miały miejsce w dobie Kulturkampfu, a więc było to już po śmierci E. Bojanowskiego ${ }^{29}$.

Zauważmy, że zdecydowanie trudniejszą sytuację spotykamy już za życia E. Bojanowskiego na obszarze Galicji. Latem 1864 roku Ministerstwo Stanu wydało dekret kasujący domy zakonne służebniczek w Galicji. Zgromadzeniu postawiono w sumie trzy zarzuty: pomijanie przepisów administracyjnych obowiązujących przy otwieraniu nowych domów zakonnych, latynizację ludności ruskiej (skargi duchowieństwa prawosławnego) oraz powiązanie zgromadzenia z powstaniem styczniowym. Finał był taki, że już w 1866 roku z Galicji musiały wyjechać służebniczki, które pochodziły spoza terenu państwa austriackiego. Piętrzące się trudności w kontaktach z domami zakonnymi w Wielkopolsce doprowadziły do zatwierdzenia przez państwo w 1875 roku nowego zgromadzenia zakonnego: Zgromadzenia Służebniczek Starowiejskich ${ }^{30}$.

Odnotujmy także, że w okresie po powstaniu styczniowym trudną sytuację spotykamy także u służebniczek w Królestwie Polskim. Zauważmy jednak, że za życia E. Bojanowskiego udało się tu otworzyć tylko dwie ochronki, które prowadziły siostry, mianowicie w Malińcu oraz w Ruszkowie. W 1865 roku zaborca postanowił wydalić służebniczki z Królestwa. Podjęte działania, aby siostry mogły pozostać, przyniosły krótkotrwałe i połowiczne korzyści. Służebniczki musiały się pozbyć swojego skromnego stroju zakonnego, tzn. zdjąć krzyże, różańce oraz welony. W Dzienniku pod datą 26 I 1865 roku E. Bojanowski zapisał: „W Malińcu zastała [s. Matylda] siostry już zapakowane do wyjazdu z Królestwa, ale Państwo przyjechali i pan Kwilecki wyjednał u rządu pozwolenie, aby siostry tam zostały. Rząd stawia tylko warunek, ażeby zdjęły krzyże, paciorki i welony. S. Matylda w konieczności przystała na to i każe już szare okrycia na głowy robić dla tych sióstr" ${ }^{\prime \prime}$. W chwili śmierci założyciela obydwie przywołane placówki zakonne już nie istniały ${ }^{32}$.

Powróćmy do rzeczywistości, którą spotykamy w okresie do 1871 roku, czyli do śmierci E. Bojanowskiego w Wielkopolsce. Jak już wspomniano, w świetle

${ }^{29}$ Zob. Z. Zieliński, Ustawy antyzakonne kulturkampfu i ich wykonanie na terenie Wielkopolski 1772-1887, „Roczniki Teologiczno-Kanoniczne” 1969, t. 16, z. 4, s. 81-82.

${ }^{30}$ M. Fąka, Ziarno..., s. 75-78, 84; A. Skrzypek, Stużebniczki Dębnickie w diecezji tarnowskiej w latach 1891-1989, Dębica 2016, s. 50-53.

${ }^{31}$ Dziennik, t, 2, s. 518.

${ }^{32}$ M. Kornacka, Edmund Bojanowski..., s. 113-114. 
źródeł, które były przedmiotem naszej analizy, nie spotykamy tu represji skierowanych na powstające dzieło ze strony władz państwowych. Nie bez znaczenia było zapewne to, że od połowy XIX wieku stosunek państwa pruskiego do Kościoła katolickiego uległ poprawie, w porównaniu z tym, z czym mieliśmy do czynienia do lat trzydziestych. Zagadnienie to oczekuje jednak na swoje szczegółowe zainteresowanie badawcze.

W przypadku rodzącego się zgromadzenia sióstr służebniczek kluczową w odbiorze państwa pruskiego mogła być specyfika, inaczej mówiąc charyzmat rodzącej się wspólnoty zakonnej. Opieka nad wiejskimi dziećmi, praca fizyczna ochroniarek, obecność małych wspólnot ochroniarek w środowisku wiejskim, szeroko rozumiana działalność charytatywna na prowincji, nie były postrzegane jako zagrożenie dla pruskiej wizji państwa. Nie zapominajmy także, że rodząca się wspólnota zakonna reprezentowała nową formę życia wspólnotowego - nie klauzurowego, ale czynnego, bezpośrednio zaangażowanego w posługę na rzecz małych społeczności wiejskich. Poza tym wydaje się, że prawdopodobnie przez pierwsze lata funkcjonowania ochroniarek urzędnikom państwowym trudno było się zorientować, że mieli tu do czynienia z powstającym dziełem zakonnym.

W luźnych notatkach E. Bojanowskiego dotyczących ochronki w Podrzeczu pod datą $18 \mathrm{~V} 1851$ roku spotykamy następujące pytanie dotyczące ochroniarek: "Czy się meldowały sołtysowi?" ${ }^{33}$. Może przez długi czas była to podstawowa i niezbędna płaszczyzna relacji powstającego dzieła z państwem?

W zewnętrznym postrzeganiu powstającego zgromadzenia zakonnego nie bez znaczenia było pozytywne ustosunkowanie się do niego właścicieli ziemskich. To oni często stanowili główne źródło zabezpieczenia materialnego ochronek. Nie bez znaczenia było także to, że dzieło ochronek wiejskich spotkało się z przychylnym przyjęciem przez opinię publiczną. Przyczyniły się do tego między innymi pozytywne teksty zamieszczane w prasie, np. w: „Dzienniku Poznańskim”, „Gazecie Codziennej”, „Przyjacielu Ludu”, „Gazecie W. Księstwa Poznańskiego”, „Nadwiślaninie” czy nawet w „Kronice Warszawskiej”34. Chociaż w tekstach podkreślano przede wszystkim samo dzieło ochronek, a nie tyle powstające zgromadzenie, to jednak przy okazji tworzono dobrą atmosfere wokół wspólnoty ochroniarek, która je prowadziła.

Rozwijające się zgromadzenie na różnych płaszczyznach doświadczyło jednak trudności, wynikających z rzeczywistości zaborów. Odwołajmy się do dwóch tekstów źródłowych:

- Fragment listu Józefa Gajewskiego z 10 VII 1856 roku, w którym napisał do E. Bojanowskiego między innymi tak: „Odgłos dobrego wpływu wywartego na lud wiejski przez Służebnice Matki Boskiej doszedł do mnie aż do Królestwa.

33 Dziennik, t. 4, s. 671.

34 Tamże, s. 74. 
Udaję się więc do W[ielmoż]nego Pana Dobrodzieja z zapytaniem, czy byłaby sposobność wystarania się o paszporty dla trzech służebnic? Ja mieszkam o dwie mile tylko od granicy pod Kaliszem. Byłbym bardzo szczęśliwy, gdybym mógł uzyskać trzy z nich dla siebie. Mam we wsi kościół, a będąc w styczności z kapucynami z Lądu, starałbym się, ażeby miały dostateczną pomoc duchowną i wszelką opiekę, jakiej by wymagały" 35 .

- Fragment listu E. Bojanowskiego do Leokadii Engeström z 4 II 1861 roku, w którym czytamy: „Co do założenia ochronki pod kierunkiem służebniczek w Królestwie, wyznać przecież musimy, że trudność koniecznego odwiedzenia takiej oddalonej ochronki przez przełożoną oraz z kosztem połączone, a również niezbędne sprowadzenie coroczne tamtych kilku służebniczek na odbywające się w tutejszym nowicjacie rekolekcje - czynią niemożliwem zaprowadzenie podobnej pojedynczej i poza granicą prowincji położonej ochronki”36.

W przytoczonych źródłach przywołano bardzo konkretne trudności związane z granicami zaborów, które miały niewątpliwy wpływ na historię zgromadzenia. Wiemy, że to właśnie przede wszystkim one doprowadziły już po śmierci E. Bojanowskiego do podziału wspólnoty aż na cztery zgromadzenia sióstr służebniczek: Zgromadzenie Sióstr Służebniczek Niepokalanego Poczęcia Najświętszej Maryi Panny (dom generalny w Żabikowie koło Poznania), Zgromadzenie Sióstr Służebniczek Najświętszej Maryi Panny Niepokalanie Poczętej (dom generalny w Starej Wsi koło Brzozowa), Zgromadzenie Sióstr Służebniczek Najświętszej Maryi Panny Niepokalanie Poczętej (dom generalny we Wrocławiu), Zgromadzenie Sióstr Służebniczek Bogarodzicy Dziewicy Niepokalanie Poczętej (dom generalny w Dębicy koło Tarnowa).

\section{Zakończenie}

Kiedy E. Bojanowski umierał (7 VIII 1871 rok) założone przez niego zgromadzenie liczyło w granicach Wielkiego Księstwa Poznańskiego 24 domy zakonne, w których mieszkało i posługiwało 98 sióstr ${ }^{37}$. Było to więc już poważne dzieło. W pojawieniu się nowej wspólnoty zakonnej można dostrzec ważny aspekt

35 Listy, t. 2, s. 141.

36 Listy, t. 1, s. 260.

37 Wydawca Dziennika Leonard Smołka wymienia 24 placówki:19 placówek zakonnych na terenie archidiecezji poznańskiej (Podrzecze, Kopaszewo, Turew, Rąbiń, Jaszkowo, Borek-Zdzież, Gołębin, Oporówko, Lubasz, Osiek, Drzązgowo, Uzarzewo, Czarnków, Poznań, Rokosowo, Granowo, Różnowo, Wielichowo, Trzebaw) oraz i 5 w granicach archidiecezji gnieźnieńskiej (Mielżyn, Niechanowo, Graboszewo, Lewków, Trzemeszno). Niecały miesiąc po śmierci E. Bojanowskiego od 1 IX 1871 roku został powołany do życia nowy dom zakonny w Kowanówce w granicach archidiecezji poznańskiej; Dziennik, t. 4, s. 707, p. 17. M. Kornacka podaje 22 domy zakonne; M. Kornacka, Edmund Bojanowski, s. 96. 
zmian wewnątrz Kościoła. Okres XVIII i XIX wieku to czas w Kościele, kiedy tradycyjne zakony, poza wyjątkami, przeżywały czas stagnacji, a dynamicznie rozwijały się nowe formy życia wspólnotowego, mianowicie zgromadzenia zakonne. Dokonywał się proces zmian mentalnościowych w postrzeganiu obecności zakonów, szczególnie żeńskich, zarówno w samym Kościele, jak i w społeczeństwie. Pojawienie się nowych wspólnot zakonnych było w znacznej mierze stymulowane istniejącymi potrzebami społecznymi. Wydaje się, że był to proces nieuchronnych zmian, w który wpisał się także Kościół funkcjonujący w granicach trzech zaborów. Oczywiście rzeczywistość zaborów, a w niej proces kasat klasztorów i domów zakonnych, odcisnął swoje piętno na historii zgromadzeń zakonnych, w tym i sióstr służebniczek.

\section{Bibliografia}

Biel B., Edmund Bojanowski 1814-1871, w: Chrześcijanie, t. 1, red. B. Bejze, Warszawa 1974, s. 87-106. Bojanowski E., Dziennik, objaśnił, skomentował i wstępem poprzedził L. Smołka, t. 1-4, Wrocław 2009. Chociej S., Twórczość literacka i działalność wydawnicza Edmunda Bojanowskiego, "Nasza Przeszłość” 1967, t. 26, s. 147-218.

Cieszkowski A., O ochronach wiejskich, Poznań 1842.

Encyklopedia wiedzy o jezuitach, oprac. L. Grzebień, Kraków 1996.

Fąka M., Ziarno wrzucone w ziemię. Edmund Bojanowski (1814-1871). Założyciel Zgromadzenia Sióstr Służebniczek N.M.P. Niepokalanie Poczętej, Wrocław 1988.

Gach P.P., Kasaty zakonów na ziemiach dawnej Rzeczypospolitej i Śląska 1773-1914, Lublin 1984.

Korespondencja Edmunda Bojanowskiego z lat 1829-1871, t. 1, Listy Edmunda Bojanowskiego z lat 1836-1871, wyd. L. Smołka, Wrocław 2001; t. 2, Listy do Edmunda Bojanowskiego z lat 1829-1868, wyd. L. Smołka, Wrocław 2001.

Kornacka M., Bojanowski Edmund, w: Encyklopedia katolicka, t. 2, Lublin 1985, kol. 738-739.

Kornacka M., Edmund Bojanowski 1814-1871, „Nasza Przeszłość” 1967, t. 26, s. 5-145.

Misiurek J., Historia i teologia polskiej duchowości katolickiej, t. 2, (w. XVIII-XIX), Lublin 1998.

Muchowicz W., Żywot Edmunda Bojanowskiego Założyciela Ochronek na ziemiach Polskich i Zgromadzenia S.S. Służebniczek B.R.D.N.P., Rzeszów 1933.

Opiela M., Integralna pedagogika przedszkolna w systemie wychowania Edmunda Bojanowskiego. Kontynuacja i zmiana, Lublin 2013.

Pękala A., Od pracy organicznej do świętości, w: Błogosławiony Edmund Bojanowski serdecznie dobry człowiek, red. S. Wilk, Lublin 2000, s. 21-48.

Reguła Zgromadzenia Służebniczek Boga Rodzicy Dziewicy Niepokalanie Poczętej, wydana drukiem nakładem Bojanowskiego, Poznań 1967.

Rehmus J., Edmund Bojanowski, w: Hagiografia polska, t. 1, red. R. Gustaw, Poznań 1971, s. 159-176.

Skrzypek A., Służebniczki Dębnickie w diecezji tarnowskiej w latach 1891-1989, Dębica 2016.

Szelęgiewicz A., Edmund Bojanowski i jego dzieło, Poznań 1966.

Zieliński Z., Kościół katolicki w Wielkim Księstwie Poznańskim w latach 1848-1865, Lublin 1973.

Zieliński Z., Ustawy antyzakonne kulturkampfu i ich wykonanie na terenie Wielkopolski 1772-1887, "Roczniki Teologiczno-Kanoniczne" 1969, t. 16, z. 4, s. 75-91. 


\section{Streszczenie}

W trudnym okresie kasat domów zakonnych w zaborze pruskim, dokładnie na obszarze Wielkopolski, powstało Zgromadzenie Sióstr Służebniczek. Było to możliwe, z jednej strony dzięki determinacji jego założyciela Edmunda Bojanowskiego, z drugiej natomiast dzięki charakterowi posługi, której podjęła się ta nowa wspólnota. W niniejszym artykule przedstawiono historię powstania oraz pierwsze lata rozwoju wspólnoty służebniczek, dokładnie do 1871 roku, czyli do śmierci E. Bojanowskiego. Podjęty temat został przedstawiony głównie z perspektywy relacji nowego zgromadzenia, zarówno do władz kościelnych, jak i świeckich. Na przykładzie historii Zgromadzenia Sióstr Służebniczek ukazano, z jednej strony specyfikę nowych form życia konsekrowanego, które spotykamy w całym Kościele w XIX wieku (w tym również na obszarze Polski podzielonej między trzech zaborców), $\mathrm{z}$ drugiej natomiast także charakter okresu zaborów, w którym przyszło powstawać oraz funkcjonować tym nowym wspólnotom zakonnym.

Słowa kluczowe: Edmund Bojanowski, Zgromadzenie Sióstr Służebniczek, zabór pruski, Wielkopolska, kasaty domów zakonnych, ochronki.

\section{Blessed Edmund Bojanowski, the founder of the Congregation of Sisters Servants - a new religious congregation in the difficult period of suppression in the Prussian partition}

\section{Summary}

During difficult period of suppression of religious houses in the Prussian partition, exactly in the Wielkopolska region, the Congregation of Sisters Servants was established. This was possible, on the one hand, thanks to the determination of its founder, Edmund Bojanowski, and, on the other hand, thanks to the character of the ministry that this new community undertook. This article presents the history of the founding and the first years of development of the community of Sisters Servants, exactly until 1871, which is until the death of E. Bojanowski. The theme was presented mainly from the perspective of the relations of the new congregation to both church and lay authorities. On the example of the history of the Congregation of Sisters Servants was presented: on the one hand, the characteristics of the new forms of consecrated life that we encounter throughout the Church in the nineteenth century (including the partitions of Poland divided between the three invaders), on the other hand, the nature of the period of partition, in which the new religious communities were formed and functioned.

Key words: Edmund Bojanowski, Congregation of Sisters Servants, Prussian partition, Wielkopolska region, suppression of religious houses, nurseries. 